\title{
Effects of Alkali Treatment On the CaP Deposition of Ti6Al4V Foams Produced by Two Different Particle Size
}

\author{
Uğur Türkan ${ }^{1}$, Mustafa Güden ${ }^{2}$ and Figen Kazak $^{3}$ \\ 1. Department of Mechanical Engineering, Gediz University, Seyrekköy, Menemen, Izmir, TURKEY \\ 2. Department of Mechanical Engineering; ${ }^{\mathrm{c} C e n t e r}$ for Materials Research, İzmir Institute of \\ Technology, Gulbahce Köyu, Urla, Izmir, TURKEY \\ 3. Nanotechnology Program, Gediz University, Seyrekköy, Menemen, Izmir, TURKEY
}

Porous Ti and Ti6Al4V (Ti64) alloy implants are known to provide better interaction with bone due to the higher degree of bone in-growth and body fluid transport through three-dimensional interconnected arrays of pores, leading to improved implant fixation [1]. Since these applications require relatively shorter bone fixation periods onto the porous surface, calcium phosphate $(\mathrm{CaP})$ coating of porous surfaces including $\mathrm{Ti}$ mesh [2,3] and the sintered beads surface coatings [4, 5] were previously investigated. Various surface treatments were further applied in conjunction with biomimetic CaP coating to fulfill the requirement for in vivo bone growth namely the formation of $\mathrm{CaP}$ (bone like apatite). Bone like apatite coating on Ti improves the surface osteoblast cell adhesion and differentiation [6] and increases the bone bonding strength by allowing an early bone opposition to the implant [7]. The present study was therefore conducted in order to investigate the effect of widely applied surface treatment of $\mathrm{Ti}$ and its alloys including alkali on biomimetic CaP deposition in an open cell Ti64 foam, potentially being used in hard tissue applications.

Open-cell Ti6Al4V foams with $\sim 60 \%$ porosity were prepared by means of the space holder method. Two different particle sizes of gas atomized spherical Ti6Al4V powders having average particle size of $94 \mu \mathrm{m}(\mathrm{P} 1)$ and $66 \mu \mathrm{m}(\mathrm{P} 2)$ were used. The green compacts were sintered at $1300{ }^{\circ} \mathrm{C}$, then it was cut to square sections in $10 \mathrm{~mm}$ length and $3 \mathrm{~mm}$ width. Alkali treatment was conducted in $100 \mathrm{ml} 10 \mathrm{M}$ $\mathrm{NaOH}$ aqueous solution at $60{ }^{\circ} \mathrm{C}$ for $24 \mathrm{~h}$. The SBF solution for in-vitro tests was prepared according to the protocol given in [8]. The crystal structures of treated and untreated foam specimens before and after SBF immersion were determined using grazing incidence (GIXRD), scanning electron microscope (SEM). The surface topography, surface roughness (Ra) and surface area difference (SAD) of the foam specimens were determined using a Nanoscope-IV Atomic Force Microscope (AFM).

The GIXRD spectra (incident angle of $\omega=0.5^{\circ}$ ) of AT P1 and P2 foam specimens revealed $\mathrm{Na}_{2} \mathrm{Ti}_{5} \mathrm{O}_{11}$ phase. Alkali treatment results in a relatively rough surface. The surface is mainly composed of a porous $\mathrm{Na}_{2} \mathrm{Ti}_{5} \mathrm{O}_{11}$ layer. The AFM analysis showed that the AT produced rougher surfaces as compared to the untreated specimens as shown in Figure 1. The surface roughness values of P1 and P2 foam samples are 8.82 and $7.24 \mathrm{~nm}$, while the surface roughness values of AT-P1 and AT-P2 are 12.6 and $18.02 \mathrm{~nm}$, respectively. Figure 2 and 3 (a-i) shows the SEM micrographs of AT P1 and P2 foam flat surfaces and interior of cells after SBF immersion. After 5-day SBF immersion the globular CaP forms on the flat surfaces of the foam specimen, while higher degree of $\mathrm{CaP}$ formation are seen in interior of the cells. After the 7-day SBF immersion, although the flat surface of the foam specimen is not coated with a continues $\mathrm{CaP}$ coating layer, the interior of the cells is fully coated with $\mathrm{CaP}$ precipitates. The increase of the SBF immersion time to 14 days results in the formation of a dense CaP layer both on the foam flat surfaces and interior of the cells. The sizes of globular $\mathrm{CaP}$ are noted in these figures bigger than that of P1 foam specimen. As opposite to P1 foam specimen, after 5-day of SBF immersion P2 foam flat surfaces are fully coated with a CaP layer (Figure 3(d)). This proves a higher rate of CaP deposition in $\mathrm{P} 2$ foam specimen as compared with $\mathrm{P} 1$ foam specimen. 

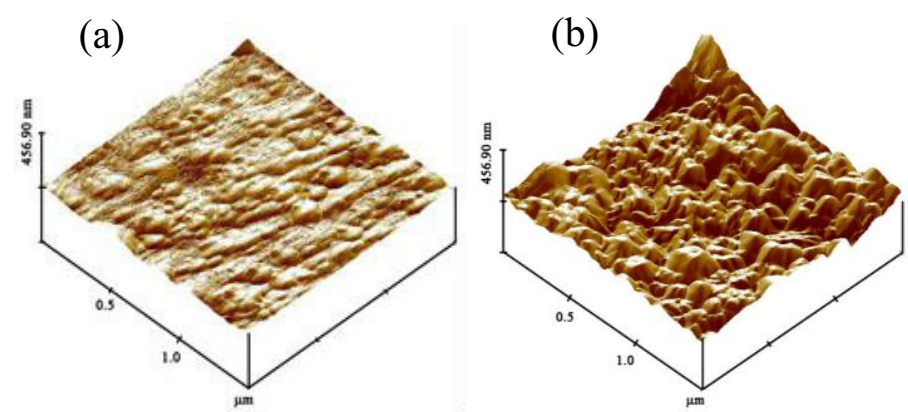

Figure 1. 3D AFM micrographs of surface topologies of untreated (a) and AT-P2 (b) foam samples.
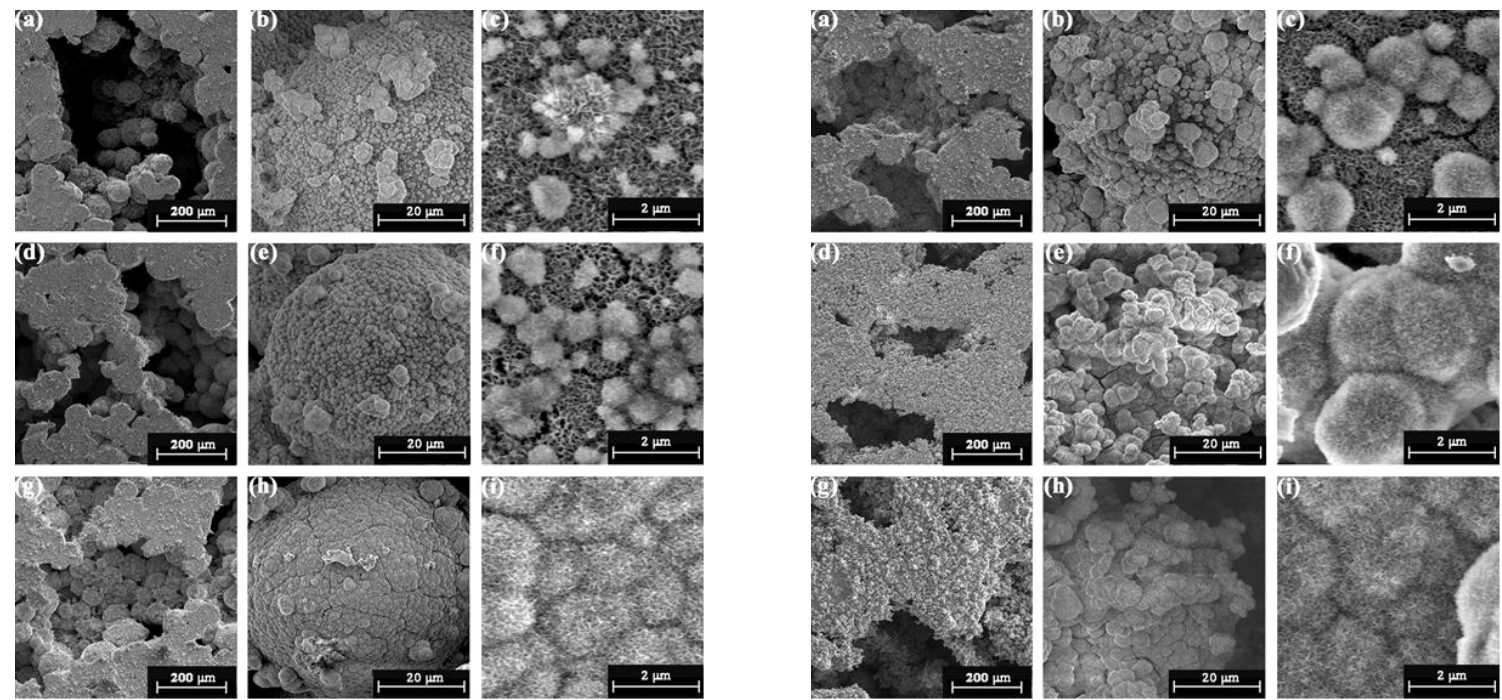

Figure 2 (left hand side) and 3 (right hand side) (a-i) shows the SEM micrographs of AT P1 and P2 foam flat surfaces and interior of cells after SBF immersion.

[1]. Pilliar, R.M., Journal of Biomedical Materials Research-Applied Biomaterials, 21, A1, p. 1-33 (1987).

[2]. Tsukeoka, T., et al., Journal of Biomedical Materials Research Part B-Applied Biomaterials, 75B, 1, p. 168-176 (2005).

[3]. Vehof, J.W.M., P.H.M. Spauwen, and J.A. Jansen, Biomaterials, 21, 19, p. 2003-2009 (2000).

[4]. Nguyen, H.Q., et al., Biomaterials, 25, 5, p. 865-876 (2004).

[5]. Barrere, F., et al., Biomaterials, 25, 14, p. 2901-2910 (2004).

[6]. Gil, F.J., et al., Materials Science \& Engineering C-Biomimetic and Supramolecular Systems, 22, 1, p. 53-60 (2002).

[7]. Yan, W.Q., et al., Biomaterials, 18, 17, p. 1185-1190 (1997).

[8]. Bayraktar, D. and A.C. Tas, Journal of the European Ceramic Society, 19, 13-14, p. 2573-2579 (1999). 